\title{
Dlaczego warto było zostać kolektorem? Kariery papieskich kolektorów generalnych w Polsce w XV wieku
}

W celu sprawnego poboru podatków nakładanych przez Stolicę Apostolską na europejskie duchowieństwo papieże wysyłali do poszczególnych krajów specjalnych urzędników skarbowych zwanych kolektorami ${ }^{1}$. Początkowo działali oni okresowo, w zależności od potrzeby, ale już za pontyfikatu Klemensa VI (1342-1352) cała Europa została podzielona na kolektorie, czyli okręgi administracji fiskalnej, w których na stałe przebywał wysłannik Kamery Apostolskiej. Najważniejszymi świadczeniami zbieranymi w kolektoriach w XIV w. były dziesięcina papieska i prokuracje ${ }^{2}$, mniejsze znaczenie miały annaty i (pobierane w niektórych krajach) świętopietrze. Pozostałe opłaty nie miały większego znaczenia w budżecie Kamery. System funkcjonował sprawnie w okresie awiniońskim, ale okres schizmy zachodniej oznaczał kryzys dla obediencji rzymskiej, w tym i dla kolektorii polskiej. Kończący rozłam w Kościele sobór w Konstancji (1414-1418) przeprowadził gruntowną reformę fiskalizmu papieskiego, likwidując zdecydowaną większość podatków od duchowieństwa. Spośród świadczeń zbieranych w lokalnych kolektoriach utrzymano w zasadzie tylko annaty i świętopietrze, tam gdzie tradycyjnie było ono zbierane. Ponadto w połowie XV w. papież Mikołaj V przeprowadził reformę poboru annat. Odtąd miały one być płacone z zasady bezpośrednio w Kamerze Apostolskiej, jeszcze przed odebraniem bulli

${ }^{1} \mathrm{~W}$ artykule wykorzystano materiały zebrane podczas realizacji grantu MNiSW pt. Supliki i bulle papieskie z lat 1431-1458 (projekt badawczy własny nr N108 073 32/3709), realizowanego na Uniwersytecie Jagiellońskim. Użyte skróty: ASV - Archivum Secretum Vaticanum; BP - Bullarium Poloniae litteras apostolicas aliaque monumenta Poloniae Vaticana continens, wyd. I. Sułkowska-Kuraś i S. Kuraś, t. IV-VII, Romae-Lublini 19922006; MPV X - Monumenta Poloniae Vaticana, t. X: Annatae e Regno Poloniae saeculi XV (1421-1503), wyd. M. D. Kowalski, Cracoviae 2002; PSB - Polski słownik biograficzny; RG - Repertorium Germanicum. Verzeichnis der in den päpstlichen Registern und Kameralakten vorkommenden Personen, Kirchen und Orte des Deutschen Reiches, seiner Diözesen und Territorien vom Beginn des Schismas bis zur Reformation, t. V-IX, Tübingen 1985-2004; MVB VII - Monumenta Vaticana res gestas Bohemicas illustrantia, t. VII, wyd. J. Eršil, Pragae 1996-2001.

${ }^{2}$ Prokuracje były opłatami od lokalnego kleru na rzecz biskupów lub ich urzędników, przeprowadzających wizytację diecezji, a potem także na rzecz wysłanników papieskich (W. L u n t, Papal Revenues in the Middle Ages, t. I, New York 1934, s. 107-111). 
prowizyjnej. W praktyce więc polscy kolektorzy w drugiej połowie XV w. zbierali niemal wyłącznie świętopietrze ${ }^{3}$.

Na czele kolektorii stał urzędnik skarbowy zwany kolektorem generalnym, który odpowiadał za zbiórkę świadczeń na swoim terytorium. Warto podkreślić, że nie należy dopatrywać się w nim, jak zdarzało się to w polskiej historiografii, dyplomaty papieskiego ${ }^{4}$. Kolektor był funkcjonariuszem Kamery, choć czasem, ze względów czysto praktycznych, zdarzało się powierzanie mu dodatkowych spraw, gdyż był jedynym przedstawicielem Stolicy Apostolskiej w Królestwie Polskim. W okresie awiniońskim utrwaliła się zasada, choć nie przestrzegano jej bezwzględnie, że na urząd kolektora w Polsce powoływano duchownych włoskich czy francuskich. Chodziło o to, by uniknąć w ten sposób uwikłania papieskiego poborcy w lokalne układy. Liczne odstępstwa od tej reguły miały miejsce w okresie schizmy ${ }^{5}$. Kolektorami zostawali zwykle duchowni średniego szczebla, cieszący się zaufaniem papieża, którzy liczyli na zrobienie kariery w Kościele dzięki pracy w służbie Kamery Apostolskiej. Wielu polskich kolektorów z XIV w. objęło z czasem nawet godności biskupów (Andrzej z Veroli arcybiskup Trani, Galhard z Carces arcybiskup Brindisi, Giacomo Guidotti biskup Imoli) ${ }^{6}$. Przyjęte w Konstancji radykalne ograniczenie podatków od kleru musiało przełożyć się na zmniejszoną atrakcyjność urzędu papieskiego kolektora, toteż w XV w. funkcję tę pełnić będą przede wszystkim Polacy. Wydaje się zasadne zbadanie, dlaczego niektórzy duchowni decydowali się pełnić urząd papieskiego poborcy, jakimi kierowali się motywami, a także w jaki sposób praca dla Kamery wpływała na ich karierę.

Christiane Schuchard wskazała, że kolektorzy liczyli przede wszystkim na szybką i udaną karierę w strukturach kościelnych, dzięki zapewnieniu sobie szczególnej przychylności papieża w przyznawaniu prowizji na beneficja. Sprzyjać temu miała możliwość szybkiego zdobycia informacji o wakatach i odpowiednio wczesne składanie suplik. Atrakcyjna była też okazja do obracania zebraną gotówką przed odesłaniem jej do Rzymu? ${ }^{7}$ Nadzieja na awans i wzbogacenie się jest dość oczywistą, wręcz narzucającą się odpowiedzią na pytanie o motywy podejmowania służby na rzecz Kamery. Przykład polskich kolektorów pokazuje jednak, że nie były to powody jedyne. Nie zawsze też udawało się zrobienie kariery.

W latach 1418-1496 papieskimi kolektorami generalnymi w Królestwie Polskim było dziewięciu duchownych. Wyraźnie dzielą się oni na dwie grupy. Pierwszą stanowili ci, którzy sprawowali swój urząd przez dłuższy czas, jak Piotr Wolfram (8 lat), Giacomino Rossi (11 lat), Mikołaj Spicymir z Krakowa (23 lata) i Uriel z Górki (21 lat). Drugą tworzyli ci, którzy pełnili funkcję krótko, przez 2-3 lata. Niektórzy

${ }^{3}$ Szerzej na ten temat: M. D. K o w a 1 s k i, Proventus Camerae Apostolicae debiti. Opłaty duchowieństwa polskiego na rzecz papiestwa w latach 1417-1484, Kraków 2010; S. S z c z u r, Skarbowość papieska w Polsce w latach 1378-1431, Kraków 2008, oraz moja recenzja z tej książki, Roczniki Historyczne 77, 2011, s. 270-281.

${ }^{4}$ Por. S. S z c z u r, Skarbowość, s. 140-141.

5 Tamże, s. 139-166.

${ }^{6}$ C. E u b e 1, Hierarchia catholica medii aevi, t. I, Monasterii 1913, s. 149, 284, 491.

${ }^{7}$ Ch. S c hu c hard, Die päpstlichen Kollektoren im späten Mittelalter, Tübingen 2000, s. $87-89$. 
z nich mieli bardzo ograniczone możliwości działania ze względu na okoliczności zewnętrzne (schizma bazylejska), jak Pietro Conti z Wenecji (1439-1442), Andrea de Palatio (1442-1445) czy Zygmunt z Giżyc (1445-1448), pozostali zaś szybko rezygnowali z kolektorstwa z innych powodów, jak Dziersław syn Michała z Karnic (1470-1472) i Andrzej Róża Boryszewski (1472-1475). Uwagę skupię przede wszystkim na kolektorach z pierwszej grupy, gdyż w ich przypadku najlepiej można prześledzić wpływ pełnionej funkcji na przebieg kariery. Większość z wymienionych duchownych ma już lepiej lub gorzej opracowane biogramy w literaturze przedmiotu. W większości przypadków przebieg ich kariery beneficjalnej przedstawiony jest jednak pobieżnie, dotyczy to zwłaszcza życiorysów w Polskim słowniku biograficznym. $\mathrm{Z}$ tego powodu opierałem się przede wszystkim na źródłach, zwłaszcza proweniencji papieskiej, by przedstawić zagadnienie możliwie precyzyjnie. Ze względu na liczne i poważne błędy w Bullarium Poloniae często konieczne było sięgnięcie do materiałów rękopiśmiennych ${ }^{8}$. Szczególną uwagę zwracałem na prowizje papieskie oraz na formę tych nadań, co niemal zawsze jest pomijane w istniejących biogramach.

Pierwszym z kolektorów generalnych w Polsce w omawianym okresie był Piotr Wolfram, syn Fabiana, piszący się z Krakowa i ze Lwowa. Był on prawnikiem, licencjatem dekretów, dyplomatą królewskim i aktywnym uczestnikiem soboru w Konstancji, jako sekretarz arcybiskupa Mikołaja Trąby ${ }^{9}$. W 1415 r. został przez sobór ustanowiony kolektorem w Królestwie Polskim, a nowy papież Marcin V zatwierdził go na tym urzędzie 3 I $1418 \mathrm{r}^{10}$ Już pierwszego dnia pontyfikatu Marcina V (21 XI 1417) Piotr uzyskał bullę prowizyjną na kanonię w kapitule krakowskiej, wakującą po śmierci Floriana z Kurdwanowa ${ }^{11}$. Wakans na kanonii nastąpił apud Sedem Apostolicam, a więc prawo udzielenia prowizji należało do głowy Kościoła, z czego kolektor skwapliwie skorzystał. Papież podtrzymał to nadanie nawet wtedy, gdy okazało się, że sam król Władysław Jagiełło zabiegał o oddanie owej kanonii swojemu sekretarzowi - Zbigniewowi Oleśnickiemu ${ }^{12}$. Przy okazji prowizji wyliczone zostały aktualnie posiadane przez Piotra Wolframa beneficja. Były to: kantoria wiślicka, altaria Św. Marcina w krakowskiej kaplicy Św. Barbary oraz kościół parafialny w Chełmcach. Piotr zobowiązał się równocześnie, że obejmując kanonię krakowską, zwolni parafię. Dopełnił tego, gdy wszedł w posiadanie kanonii w 1418 r. ${ }^{13}$ Jak widać, niezwykle ważne i prestiżowe beneficjum kanonika stołecznej kapituły Piotr zawdzięczał służbie papieskiej i nastąpiło to nawet wbrew woli króla.

Dwa tygodnie po pierwszym nadaniu, 6 XII 1417 r., Piotr Wolfram złożył suplikę o prowizję papieską na kancelarię kapitulną wrocławską, wakującą w Kurii po śmierci

8 Zob. M. D. Kow a 1 s k i, Uwagi o „Bullarium Poloniae”. Spojrzenie na koncepcję edycji i wykonanie, Studia Źródłoznawcze 45, 2007, s. 71-97.

${ }^{9}$ M. Z w i e r c a n, Piotr Wolfram z Krakowa, w: PSB XXVI (1981), s. 403-406.

10 BP IV, nr 141, 180.

11 ASV, Reg. Lat. 188, f. 62r-62v. Regest w BP IV, nr 2, jest niepełny, pominięto tam fakt posiadania przez Piotra kościoła parafialnego w Chełmcach i obowiązek jego zwolnienia; zob. też BP IV, nr 8.

${ }_{12}$ Codex epistolaris saeculi decimi quinti, t. II, wyd. A. Lewicki, Kraków 1891, nr 79.

13 Parafię w Chełmcach zwolnił niedługo po 25 III 1418 r., zob. BP IV, nr 223 (z uwagami niżej, przyp. 16), 516. 
Wawrzyńca Sachse ${ }^{14}$. Nadanie to nie zostało zrealizowane, kolektor nie zadbał nawet o wyekspediowanie bulli prowizyjnej ${ }^{15}$, gdyż wkrótce pojawiła się możliwość objęcia znacznie bardziej atrakcyjnego beneficjum - po śmierci Michała z Krowicy zawakowała bowiem scholasteria gnieźnieńska. Piotr uzyskał na nią papieską prowizję 25 III $1418 \mathrm{r} \cdot{ }^{16} \mathrm{~W}$ dokumencie tym podano, że oprócz wymienionych wyżej trzech beneficjów i dwóch prowizji z końca 1417 r., Piotr ma jeszcze ekspektatywy na kanonie lub prałatury w kapitułach w Poznaniu i Wrocławiu. W prowizji znalazło się zastrzeżenie, że jeśli kolektor obejmie scholasterię gnieźnieńską, to musi zrzec się posiadanej altarii i prowizji na kancelarię we Wrocławiu, co też wkrótce faktycznie nastąpiło.

Ze względu na to, że Piotr Wolfram posiadał już prałaturę kantora w Wiślicy, realizacja jednego z dwóch wyżej wspomnianych papieskich nadań (na kancelarię wrocławską lub na scholasterię w Gnieźnie) prowadziłaby do niedozwolonej kumulacji w jego ręku tzw. beneficjów niekompatybilnych, a więc takich, których nie wolno było posiadać równocześnie ${ }^{17}$. $\mathrm{Z}$ tego powodu polski kolektor prosił o dyspensę na dożywotnią kumulację, lecz Marcin V zgodził się na kumulowanie kantorii wiślickiej z drugą godnością tylko przez jeden rok, $\mathrm{z}$ prawem do dokonania $\mathrm{w}$ tym czasie zamiany jednej z prałatur na beneficium compatibile. Tego rodzaju czasowa dyspensa była typowym postępowaniem w odniesieniu do osób cieszących się łaską papieża. Duchowny nie musiał opuszczać natychmiast posiadanego beneficium incompatibile, ale otrzymywał czas na jego zamianę na inne, które już można było kumulować. Choć wakans na scholasterii gnieźnieńskiej prawdopodobnie nie nastąpił w sposób powodujący zarezerwowanie jej do papieskiej dyspozycji, to Piotr Wolfram zdołał wejść w jej posiadanie. Przeciwko niemu stanął jednak konkurent, Jakub Jabłowski, który otrzymał scholasterię z nadania arcybiskupa (auctoritate ordinaria). Chcąc uniknąc długotrwałego sporu, obaj rywale doszli do porozumienia. Papieski kolektor zdecydował się odstąpić Jabłowskiemu kantorię wiślicką (którą i tak musiałby zwolnić lub zamienić), w zamian za co Jakub zrzekł się wszelkich praw do scholasterii. Ta zamiana została zatwierdzona przez papieża $19 \mathrm{~V} 1419 \mathrm{r}^{18}$

Jak widać, jeszcze w 1418 r. kolektor posiadał trzy beneficja. W wyniku opisanych wyżej nadań, rezygnacji i zamiany Piotr Wolfram stał się posiadaczem tylko dwóch, ale bardzo prestiżowych i bogatych beneficjów: scholasterii gnieźnieńskiej i kanonii krakowskiej. Wkrótce jednak jego stan posiadania zwiększył się o kolejne prebendy. Postarał się o papieską zgodę na możliwość swobodnej zamiany swoich beneficjów,

${ }^{14}$ BP IV, nr 85; zob. też nr 223.

${ }^{15}$ MVB VII, nr 568.

16 ASV, Reg. Lat. 196, f. 56r-56v (regest w BP IV, nr 223, jest niepełny i błędny). Suplika do tej bulli: MVB VII, nr 238; BP IV, nr 742 (tzw. reformatio supliki).

${ }_{17}$ Konstytucja Exsecrabilis z 1317 r. zakazywała łączenia w jednym ręku niektórych typów beneficjów, które z tego powodu określane były jako incompatibilia. Bez dyspensy nie wolno było jednocześnie posiadać beneficjów cum cura animarum (przede wszystkim kościołów parafialnych) oraz prałatur w kapitułach katedralnych i kolegiackich, nawet jeśli były one beneficjami sine cura; zob. M. D. Kow a lski, Proventus, s. 21-22. Kolejnym beneficjum niekompatybilnym w posiadaniu Piotra był kościół parafialny w Chełmcach, ale miał go niebawem zwolnić, więc nie stanowiło to problemu.

${ }^{18} \mathrm{BP}$ IV, $\mathrm{nr} 451$. 
zarówno tych posiadanych obecnie, jak i tych, które obejmie w przyszłości ${ }^{19}$. Trzy lata później Wolfram został ponadto przyjęty do grona familiarisów papieskich ${ }^{20}$.

Dnia 28 III 1422 r. Piotr Wolfram otrzymał kolejną prowizję papieską, tym razem na kanonię poznańską, wakującą po śmierci Mikołaja Borsnicza ${ }^{21}$. Według supliki kolektor był już ponadto kanonikiem w katedrze wrocławskiej. Brak papieskich dokumentów prowizyjnych $w$ tej sprawie, a także brak śladów wniesienia opłaty annatowej w aktach Kamery Apostolskiej może świadczyć o tym, że tę ostatnią prebendę uzyskał z nadania biskupiego. W ten sposób Piotr stał się posiadaczem aż czterech beneficjów. Wreszcie, korzystając z posiadanej facultas permutandi, 5 VII 1426 r. kolektor dokonał zamiany beneficjów z Andrzejem Myszką z Nieprześni. W zamian za scholasterię gnieźnieńską i kanonię krakowską uzyskał od Andrzeja archidiakonat krakowski, co zmniejszyło liczbę posiadanych beneficjów z powrotem do trzech ${ }^{22}$. Utrzymał je bez zmian do swej śmierci 9 X $1428 \mathrm{r}^{23}$

Jak widać, podczas pełnienia funkcji kolektora papieskiego Piotr Wolfram prowadził aktywną ,politykę beneficjalną”. Nie był jednak typem „kolekcjonera” beneficjów i nigdy nie posiadał jednocześnie wielkiej liczby prebend (tylko w latach 1422-1426 miał ich cztery), choć w ciągu ośmiu lat sprawowania urzędu przez jego ręce przewinęło się aż 8 różnych beneficjów kościelnych ${ }^{24}$. Korzystając z papieskich przywilejów, skutecznie zamieniał kolejne prebendy na coraz bogatsze i bardziej prestiżowe. Nie ulega wątpliwości, że tak efektywne zabiegi były możliwe dzięki pełnionej funkcji papieskiego poborcy, która zapewniała mu przychylność głowy Kościoła w udzielaniu prowizji i innych łask. Oprócz bogatych beneficjów Piotr posiadał jeszcze dochody z pełnionego urzędu kolektorskiego. Nie ograniczały się one tylko do zwyczajowej pensji, stanowiącej ekwiwalent kolejnej dobrej godności kościelnej ${ }^{25}$. Stanisław Szczur słusznie zauważył, że dokonując operacji finansowych pieniędzmi zebranymi dla Kamery Apostolskiej, Piotr wszedł w funkcję bankiera, co przynosiło mu prowizję od sum przesyłanych do Kurii. Zwyczajowo wynosiła ona $10 \%$ transferowanej kwoty. Biorąc pod uwagę, że kolektor każdego roku wysyłał w tym czasie średnio niespełna 1000 florenów ${ }^{26}$, zyskiwał dzięki temu kolejne

19 Tamże, nr 308 (21 VII 1418).

20 Tamże, nr 1530 (13 VI 1425).

${ }^{21}$ Tamże, nr 994, zob. też nr 1539 (21 VI 1425). Z innej supliki, tamże, nr 987 (19 III 1422), wynika, że Wolfram miał już wcześniej inną kanonię w kapitule poznańskiej, którą teraz zamienił na lepszą prebendę po Borsniczu.

22 Tamże, nr 1758; MPV X, nr 154, 155.

${ }^{23}$ M. D. K o w a $1 \mathrm{~s} \mathrm{k} \mathrm{i,} \mathrm{Zapomniany} \mathrm{kalendarz} \mathrm{-} \mathrm{nekrolog} \mathrm{kapituły} \mathrm{krakowskiej} \mathrm{z} \mathrm{XV} \mathrm{wieku,}$ Nasza Przeszłość 87, 1997, s. 135-136. Po śmierci Piotra Wolframa zawakowały kanonie we Wrocławiu i Poznaniu oraz archidiakonat w Krakowie (BP IV, nr 2215, 2224, 2233; MPV X, nr 258, 259, 266).

${ }^{24}$ Kanonie katedralne w Krakowie, Poznaniu, Wrocławiu, kantoria i scholasteria gnieźnieńska, parafia w Chełmcach, altaria Św. Marcina w kościele Św. Barbary w Krakowie, archidiakonat krakowski.

${ }^{25}$ Kolektor otrzymywał 365 florenów rocznie, z czego jednak musiał opłacić koszty sprawowania urzędu, w szczególności wynagrodzenie swoich subkolektorów; w praktyce zostawała mu ok. połowa powyższej kwoty (M. D. Kow a l s k i, Proventus, s. 214).

${ }^{26}$ Tamże, s. 206, 209. 
kilkadziesiąt florenów rocznego dochodu (a więc tyle, ile dawałaby dodatkowa prebenda). $Z$ pewnością $\mathrm{w}$ sumie czyniło to Piotra Wolframa bardzo zamożnym człowiekiem.

Następcą Piotra Wolframa został Włoch Giacomino Rossi ${ }^{27}$. Nominację na kolektora zawdzięczał być może poparciu przyjaciela, kurialisty Bartolomea de Monte lub wstawiennictwu kardynała Gabriela Condulmar (późniejszego papieża Eugeniusza IV), którego był familiarisem. Po raz pierwszy przybył do Polski już w 1424 r., reprezentując papieża Marcina V na chrzcie królewicza Władysława ${ }^{28}$. Kolektorem został mianowany na początku stycznia 1426 r., a kolejny papież utrzymał go na urzędzie, który Rossi sprawował aż do swej śmierci jesienią 1436 r. ${ }^{29}$ Można uznać, że był ostatnim kolektorem starego typu, na wzór urzędników z XIV w.: pochodził z Italii i w momencie nominacji nie posiadał wyższych godności kościelnych. Do działalności Giacomina Rossiego zachował się niezwykle bogaty zespół źródeł, m.in. kilkanaście prywatnych listów ${ }^{30}$. Korespondencja ta pozwala ponad wszelką wątpliwość stwierdzić, że powodem przyjęcia przez Giacomina urzędu kolektorskiego było pragnienie awansu w strukturach kościelnych i objęcia bogatych beneficjów. Podstawowym tematem jego listów są właśnie zabiegi o uzyskanie kolejnych prowizji papieskich i troska o przebieg procesów toczonych w Kurii. Niekiedy prośby do przyjaciela-kurialisty przybierają wręcz formę nagabywania o jeszcze pilniejsze pilnowanie interesów Giacomina.

W momencie nominacji kolektorskiej Rossi był kanonikiem kościoła S. Maria di Castello w Genui i było to jego jedyne beneficjum ${ }^{31}$. Bulla z 12 II 1426 r. informuje, że w latach wcześniejszych Giacomino uzyskał kilka ekspektatyw: w 1418 r. na kanonię w Turynie oraz na beneficjum w diecezji Asti, a w 1424 r. na prebendy pozostające w dyspozycji biskupów Genui i Albenga oraz Wrocławia i Krakowa. Ponadto toczył też wtedy bezskutecznie spór o kościół parafialny NMP de Casellis (diecezja Turyn) oraz zadbał o uzyskanie dyspensy na kumulację dwóch beneficjów niekompatybilnych ${ }^{32}$. Żadnej z powyższych ekspektatyw nie zdołał zrealizować. Przyznanie Rossiemu ekspektatywy na beneficja w dalekiej Polsce należy wiązać z jego wyjazdem na chrzest królewicza Władysława i planowanym już wtedy zapewne powierzeniem mu funkcji kolektora. Upragnione bogate beneficjum uzyskał dopiero po półtora roku służby na urzędzie kolektorskim. Dnia 7 VII 1427 r. otrzymał papieską prowizję motu proprio na prepozyturę w Opolu, wakującą in Romana Curia po

${ }^{27}$ W źródłach, a w ślad za tym i w literaturze przedmiotu, występuje jako Iacobinus de Rubeis.

${ }^{28}$ M. D. K o w a $1 \mathrm{~s} \mathrm{k}$ i, Rationes Iacobini de Rubeis, collectoris in Regno Poloniae (14261434). Rachunki Giacomina Rossiego, papieskiego kolektora generalnego w Polsce, z lat 1426-1434, Studia Źródłoznawcze 49, 2011, s. 62.

${ }^{29}$ Te n ż e, Proventus, s. 193-194.

${ }^{30}$ Opublikowane w: Una corrispondenza fra curiali della prima meta del quattrocento, wyd. A. Mercati, w: A. M e r c a t i, Dall'Archivio Vaticano, Città del Vaticano 1951 (Studi e testi, t. 157), s. 47-63; listy adresowane do Giacomina, tamże, s. 72-81. W czasie kwerendy znalazłem jeszcze kilka kolejnych, niepublikowanych listów Giacomina.

${ }^{31}$ BP IV, nr 1651, 1659-1669; M. D. K o w a 1 s k i, Rationes Iacobini, s. 70-72, 75.

32 ASV, Reg. Lat. 259, f. 247r-248r; zob. też ASV, Reg. Suppl. 216, f. 62r-63r (regest w BP IV, nr 2041, jest niepełny). 
śmierci kardynała Rainalda Brancacci wraz z prawem jej dożywotniej kumulacji $\mathrm{z}$ dowolnym innym beneficium incompatibile ${ }^{33}$.

Mniej więcej w tym czasie kolektor musiał otrzymać papieskie nadanie kanonii katedralnej w Krakowie, o którą toczył później długotrwały spór z Mikołajem Głębockim i z Pawłem z Giżyc, który to spór ostatecznie zakończył się porażką Rossiego ${ }^{34}$. Niepowodzeniem zakończyły się też zabiegi o archidiakonat w kolegiacie w Głogowie, wakujący po śmierci Mikołaja Neudorffa (zmarł zapewne pod koniec 1426 r. $)^{35}$. Jesienią 1427 r. Giacomino toczył już w Kurii spór o tę prałaturę z Henrykiem Rolle ${ }^{36}$, ale najwyraźniej nie liczył na sukces, gdyż po otrzymaniu nadania typu si neutri nie zabiegał nawet o wystawienie bulli ${ }^{37}$. Proces przeciągnął się do początku 1429 r., kiedy to archidiakonat głogowski ostatecznie objął wpływowy kurialista Henryk Senftleben ${ }^{38}$.

Kolejnym beneficjum, o które zabiegał polski kolektor, była kantoria w kapitule katedralnej w Krakowie. Jej posiadaczem był podkanclerzy Stanisław Ciołek, którego Władysław Jagiełło przeznaczył na biskupstwo poznańskie. Po trwającym półtora roku sporze między królem a papieżem o obsadę wielkopolskiej katedry Marcin V zgodził się ostatecznie na kandydaturę Ciołka ${ }^{39}$. Dowiedziawszy się od królewskiego posła o papieskiej decyzji, Giacomino natychmiast (listem z 13 I 1428 r.) powiadomił Bartolomea de Monte, swojego przyjaciela w Kurii, o beneficjach mających zawakować po promocji podkanclerzego (kantorii krakowskiej, kanonii poznańskiej i kanonii włocławskiej) i poprosił go, by złożył supliki o papieskie prowizje dla Rossiego. Posłał też Bartłomiejowi weksel na 30 florenów na pokrycie kosztów ${ }^{40}$. Sprawa została załatwiona po myśli kolektora, gdyż 22 V 1428 r., zaledwie dzień po wystawieniu bulli prekonizacyjnej dla Stanisława Ciołka, Rossi otrzymał rezerwację motu proprio kantorii krakowskiej. Przy tej okazji otrzymał dyspensę na dożywotnie kumulowanie dwóch beneficjów niekompatybilnych, a przez 3 lata mógł nawet posiadać trzy beneficja tego typu, z prawem zamiany jednego z nich na beneficium compatibile $^{41}$. Kolektor zapewnił sobie w ten sposób możliwość równoczesnego dzierżenia kantorii krakowskiej i prepozytury w Opolu oraz, na wypadek wygrania w Kurii sporu o inną prałaturę, zyskiwał czas na zamianę jej na inną prebendę. Choć ze względu na sposób wakansu kantoria w Krakowie podlegała rezerwacji

${ }^{33}$ ASV, Reg. Suppl. 214, f. 42r-42v; Reg. Lat. 275, f. 180r-181v (regest w BP IV, nr 1995, jest niepełny). Beneficjum zwalniane przez kardynała, jak było właśnie w tym przypadku, podlegało rezerwacji papieskiej.

${ }^{34}$ BP IV, nr 2041, 2247, 2256; Una corrispondenza, nr 30 (s. 51), 31, 32.

${ }^{35}$ H. G e r l i c, Kapituła głogowska w dobie piastowskiej i jagiellońskiej (1120-1526), Gliwice 1993, s. 228, 274.

${ }^{36}$ MVB VII, nr 1878; BP IV, nr 2041; H. G e r l i c, Kapituła głogowska, s. 222.

${ }^{37}$ MVB VII, nr 2003. Nadanie typu si neutri (lub si nulli) było prowizją udzielaną na beneficjum, o które toczył się spór w Rocie, na wypadek gdyby nie zostało ono przysądzone żadnej z procesujących się stron.

${ }^{38}$ Una corrispondenza, nr 30, 31; MVB VII, nr 2026, 2042; H. G e r li c, Kapituła głogowska, s. 222.

39 Z. K o w a $1 \mathrm{~s} \mathrm{k}$ a, Stanisław Ciołek (+1437), podkanclerzy królewski, biskup poznański, poeta dworski, Kraków 1993, s. 64-71.

${ }^{40}$ Una corrispondenza, $\mathrm{nr} 28$.

${ }^{41}$ ASV, Reg. Lat. 278, f. 162r-164r (regest w BP IV, nr 2130, jest niepełny). 
papieskiej i prawa Rossiego do tej prałatury były nie do podważenia, kolektor nie zdołał nigdy wejść w jej posiadanie. Kantorię objął najpierw Mikołaj Lasocki, a potem Wincenty Kot z Dębna. Rossi odwoływał się wprawdzie do sądu papieskiego, gdzie uzyskał korzystne dla siebie wyroki, ale nie zdołał ich wyegzekwować ${ }^{42}$. Proces o kantorię ciągnął się latami przed audytorem papieskim (trwał jeszcze w grudniu 1434 r. $)^{43}$, ale kolektor, zniechęcony bezowocnymi zabiegami o stallę w wawelskiej katedrze, w 1429 r. przeniósł się na stałe do Wrocławia ${ }^{44}$.

W stolicy śląskiej diecezji kariera beneficjalna Giacomina Rossiego też nie rozwinęła się zgodnie z jego oczekiwaniami. Dopiero po upływie ponad dwóch lat od przeniesienia się na Śląsk kolektor zdołał wejść do grona kanoników katedralnych we Wrocławiu. Najpierw, zapewne na początku 1429 r., próbował objąć wakującą kanonię, ale sprawa przerodziła się w długotrwały spór ze Stefanem Wolffem, który pozostawał $\mathrm{w}$ faktycznym posiadaniu prebendy ${ }^{45}$. Skuteczne okazało się dopiero nadanie dokonane auctoritate ordinaria przez biskupa Konrada, który późną jesienią 1431 r. przekazał Rossiemu kanonię, wakującą po śmierci Jana Hellinga ${ }^{46}$. Być może przez tak życzliwe postępowanie względem Giacomina pogrążony w kłopotach finansowych biskup Konrad chciał pozyskać sobie terenowego reprezentanta Kamery Apostolskiej.

Fiaskiem zakończyły się natomiast starania o objęcie prepozytury wrocławskiej, najwyższej prałatury w kapitule katedralnej. Po raz pierwszy Giacomino zabiegał o nią w 1429 r. W styczniu tego roku przebywający w Krakowie Rossi dowiedział się od swojego śląskiego subkolektora, że prepozyt Jan Strelicz ciężko zachorował i niewątpliwie wkrótce umrze. Kolektor poprosił więc listownie swoich rzymskich protektorów o złożenie stosownej supliki o mającą zawakować prepozyturę, najlepiej w formie motu proprio ${ }^{47}$. Suplika została pozytywnie rozpatrzona przez papieża 7 III 1429 r. ${ }^{48}$ Pośpiech okazał się jednak nadmierny, gdyż Jan Strelicz zmarł dopiero 15 sierpnia, więc nadania okazały się nieważne. Wprawdzie list Giacomina wskazuje, że liczył on jeszcze na uzyskanie prowizji ${ }^{49}$, ale bullę prowizyjną na prepozyturę we Wrocławiu uzyskał 26 IX 1429 r. audytor papieski Mikołaj Zeisselmeister ${ }^{50}$.

${ }^{42}$ Dokładny opis starań Rossiego o kantorię krakowską zob. M. D. K ow a ls k i, Rola prowizji papieskich w obsadzaniu prebend katedralnych za czasów Zbigniewa Oleśnickiego, w: Zbigniew Oleśnicki, książę Kościoła i mąż stanu, Kraków 2006, s. 184-185, 187-189.

${ }^{43}$ ASV, Reg. Lat. 323, f. 128r-129v (regest w BP V, nr 366, jest niepełny).

44 Jeszcze w styczniu 1429 r. Rossi przebywał w Krakowie, a we wrześniu tr. znajdował się już we Wrocławiu, zob. Una corrispondenza, nr 31, 32.

${ }_{45}$ Tamże, nr 32-34; ASV, Reg. Suppl. 275, f. 89r-89v (RG V, nr 3536; niepełny regest w BP VI, nr 99, nie zawiera informacji o trwającym sporze o kanonię wrocławską).

${ }^{46}$ Una corrispondenza, nr 34, s. 57-58. Na wszelki wypadek Rossi postarał się także o konfirmację papieską (tzw. nova provisio): RG V, nr 3536; BP VI, nr 99. W późniejszym czasie (1434) Rossi próbował, chyba bezskutecznie, zamienić posiadaną prebendę na inną w tej samej kapitule, wakującą po śmierci prepozyta Mikołaja Zeisselmeistra (RG V, nr 3536).

${ }^{47}$ Una corrispondenza, nr 30 (list z 5 I 1429). Prośbę ponowił w kolejnym liście z 15 I 1429 r. (tamże, nr 31).

${ }^{48}$ MVB VII, nr 2035.

49 Una corrispondenza, nr 32.

${ }^{50}$ MVB VII, nr 2089, 2090. Zob. też K. D o l a, Wrocławska kapituła katedralna w XV wieku, Lublin 1983, s. 404. 
Ponowny wakat na prepozyturze wrocławskiej miał miejsce już pięć lat później, gdy 20 VII 1434 r. zmarł Mikołaj Zeisselmeister. Giacomino bawił wtedy w Kurii Rzymskiej. Natychmiast, już następnego dnia, współpracujący z kolektorem kupiec i bankier wrocławski Hans Banke (starszy) wysłał do Rossiego wiadomość o wakansie wraz z ostrzeżeniem, że kandydaci na prepozyturę już wyruszyli do Italii ${ }^{51}$. Dzięki temu Rossi zdołał ubiec wszystkich konkurentów i już 26 VIII 1434 r. otrzymał nadanie papieskie w formie motu proprio ${ }^{52}$. Mimo prośby nie uzyskał natomiast dyspensy na dożywotnie kumulowanie prepozytur opolskiej i wrocławskiej. Prośbę o dyspensę ponowił 27 VI 1436 r., ale otrzymał zgodę na łączenie obu prałatur jedynie przez 5 lat, z prawem zamiany ${ }^{53}$. Choć prepozytura była objęta rezerwacją papieską i prawa Rossiego wydawały się niepodważalne, to i tym razem nie objął on upragnionej prałatury. W jej faktyczne posiadanie wszedł bowiem Mikołaj Gramis i kolejny raz kolektor musiał wszcząć proces sądowy w Kurii. Choć uzyskał korzystny wyrok, to i tak nie zdołał objąć prebendy ${ }^{54}$. Przeciągający się spór zakończyła śmierć Giacomina wczesną jesienią 1436 r. ${ }^{55}$ Poza staraniami o wymienione wyżej beneficja, Rossi podejmował jeszcze zabiegi o uzyskanie nadań papieskich na prebendę w Genui (1429-1431) ${ }^{56}$, kanonię lub prałaturę w Gnieźnie i Wrocławiu ${ }^{57}$ oraz na dziekanię wrocławską $(1432)^{58}$, ale okazały się one bezowocne.

Spoglądając na całą karierę beneficjalną Giacomina Rossiego, można zauważyć, że mimo intensywnych i skutecznych starań o papieskie prowizje, kolektor nie zdołał osiągnąć większości z nadanych mu beneficjów. Oprócz posiadanej jeszcze przed nominacją kanonii kolegiackiej w Genui zdołał objąć prepozyturę opolską (1427) oraz kanonię katedralną we Wrocławiu (1431), ale tę ostatnią jednak dopiero auctoritate ordinaria. Porażki kolektora są szczególnie uderzające w przypadku zabiegów o kantorię krakowską i o prepozyturę wrocławską. Podlegały one rezerwacji papieskiej, Rossi uzyskał do nich niedające się podważyć prawa, a później wygrał procesy w Kurii, a mimo to nie zdołał wejść w ich posiadanie ze względu na opór lokalnego środowiska. Dzięki zachowanej korespondencji widać, jak zwodziła i wręcz lekceważyła go krakowska kapituła. Dwukrotnie prosił o przysłanie

${ }^{51}$ Podane tu szczegóły znajdują się w niedrukowanym liście od Hansa Banke do Rossiego, który zostanie opublikowany w przygotowywanej przeze mnie książce poświęconej kolektorii polskiej pod rządami tego kolektora.

52 ASV, Reg. Suppl. 297, f. 293r-294r; Reg. Suppl. 298, f. 135r (suplika reformacyjna); Reg. Lat. 326, f. 171v-173v (bulla wyekspediowana już 9 IX 1434); RG V, nr 3536; regest w BP V, nr 327, jest mocno niepełny.

${ }^{53}$ ASV, Reg. Suppl. 324, f. 55v-56r; Reg. Lat. 345, f. 247v-248r (regest w BP V, nr 541, jest błędny).

${ }^{54}$ ASV, Reg. Lat. 340, f. 258r-258v (12 VII 1436); regest w BP 5, nr 544, jest niepełny. Wzmianka o toczącym się procesie pojawia się w liście z 26 VIII 1435 r. (Una corrispondenza, nr 37).

${ }_{55}^{5}$ Giacomino Rossi wspomniany został jako zmarły 18 X 1436 r. (BP V, nr 568, 569).

${ }^{56}$ Una corrispondenza, $\mathrm{nr} 30,32$; RG V, nr 3536. Być może Rossi liczył się z możliwością odwołania go z urzędu kolektora i dlatego postarał się o ekspektatywy na beneficja w Genui.

${ }^{57} \mathrm{RG} \mathrm{V}$, nr 3536 (24 IV 1431); zob. też Una corrispondenza, nr 33 (list z 15 X 1431).

${ }^{58}$ Una corrispondenza, $\mathrm{nr} 35$. 
z Italii pisma z potwierdzeniem swego szlachectwa ${ }^{59}$, dobrych rad udzielał mu arcybiskup, sugerując, by postarał się papieski list protekcyjny do króla, tymczasem zaś kantorię objął Mikołaj Lasocki, a przy ponownym wakansie - Wincenty Kot $\mathrm{z}$ Dębna ${ }^{60}$. Nie wiadomo dokładnie, co było powodem tak wielu niepowodzeń kolektora w staraniach o prałatury. Może była to rosnąca niechęć wobec obcokrajowców w kapitule, a być może sam kandydat był osobą zbyt nisko urodzoną lub nie mającą większego autorytetu.

Po śmierci Giacomina Rossiego następnym papieskim poborcą w Polsce został w lutym 1437 r. Mikołaj Spicymir z Krakowa. Papiestwo wróciło więc w ten sposób do powierzania urzędu kolektora Polakom. Po niespełna trzech latach Mikołaj opowiedział się za soborem bazylejskim i został zastąpiony przez kolejnego wysłannika. Na urząd wrócił w 1449 r., dlatego jego karierę przedstawię nieco dalej. Gdy Kościół polski niemal w całości przeszedł na stronę soboru, Eugeniusz IV z konieczności musiał powierzyć kolektorię duchownym włoskim. Najpierw urząd objął doktor dekretów Pietro Conti z Wenecji (1439-1442?), co do którego nie ma nawet pewności, czy przybył do Polski, po nim zaś Andrea de Palatio (1442-1445) ${ }^{61}$. Ten ostatni wprawdzie zjawił się w powierzonym mu kraju, ale jego działalność ograniczała się do diecezji poznańskiej, na czele której stał zwolennik rzymskiego papieża - Andrzej z Bnina ${ }^{62}$. Kolektor przebywał też przez dłuższy czas na Węgrzech, towarzysząc królowi Władysławowi w wyprawie warneńskiej. Z oczywistych powodów objęcie kolektorii polskiej nie mogło więc mieć wpływu na kariery obu tych duchownych.

Kolejnym kolektorem w Polsce (i w Czechach), mianowanym przez Eugeniusza IV bullą z 16 XII 1445 r., został Zygmunt syna Wacława z Giżyc ${ }^{63}$. Był on bratem biskupa płockiego Pawła Giżyckiego (1439-1463), który w tym czasie zaczął na powrót skłaniać się ku rzymskiemu papieżowi ${ }^{64}$. Przez pierwsze 2 lata urzędowania nowy kolektor musiał jednak działać $\mathrm{w}$ bardzo niekorzystnych - z punktu widzenia interesów Kamery Apostolskiej - warunkach, gdyż tylko biskup poznański uznawał jeszcze władzę Eugeniusza IV, a pozostała część kolektorii polskiej opowiadała się za soborem. Sytuacja zmieniła się dopiero w 1447 r., gdy Kazimierz Jagiellończyk złożył obediencję papieżowi Mikołajowi V i to samo wymógł na polskim Kościele. Nie dziwi zatem fakt, że dopiero w 1448 r. w registrach Kamery odnotowano pierwszą od niemal dekady wpłatę od polskiego kolektora (tylko 200 florenów) $^{65}$.

Zygmunt Giżycki na długo przed swą nominacją był już posiadaczem ważnych beneficjów: dziekanii kruszwickiej (przed 17 I 1432), a w późniejszym czasie dziekanii płockiej (od 1444) i kanonii w tejże kapitule katedralnej, a także był prebendarzem

${ }^{59}$ Najwyraźniej kapituła powołała się na przywilej papieski z 1414 r., zamykający wstęp do kapituły plebejuszom bez tytułu uniwersyteckiego (a Rossi takowego nie miał).

${ }^{60}$ M. D. K ow a 1 s k i, Rola prowizji, s. 188-189.

${ }^{61}$ Te n ż e, Proventus, s. 194-195.

${ }^{62}$ Szczegółowo o działalności tego kolektora t e n ż e, Andrzej de Palatio, papieski kolektor generalny w Polsce w latach 1442-1445, w: Ecclesia - regnum - fontes. Studia z dziejów średniowiecza (w druku).

${ }^{63}$ Te n ż e, Proventus, s. 195.

${ }^{64}$ T. G r a ff, Episkopat monarchii jagiellońskiej w dobie soborów powszechnych XV wieku, Kraków 2008, s. 283-287.

${ }^{65}$ M. D. K ow a $1 \mathrm{~s} \mathrm{ki}$, Proventus, s. 207. 
Św. Św. Piotra i Pawła w katedrze płockiej $(1444)^{66}$. Niedługo po objęciu kolektorii polskiej przeszedł z dziekanii na prepozyturę płocką, na którą 10 VI 1446 r. uzyskał prowizję papieską ${ }^{67}$. W tym samym czasie, po pięcioletnich studiach w Bolonii, uzyskał na tamtejszym uniwersytecie doktorat dekretów (5 IV 1446). Bardzo szybko, gdyż po niespełna trzech latach (1448), odszedł z urzędu kolektora. Choć, jak wyżej wspomniano, pół roku po nominacji Giżycki otrzymał prowizję papieską na prepozyturę płocką, to nie podlegała ona wtedy rezerwacji papieskiej i o jej obsadzie zapewne zdecydował ordynariusz. Nie wydaje się więc, by sprawowanie urzędu kolektora w jakikolwiek sposób wpłynęło na karierę Zygmunta. Decydujące znaczenie miała protekcja brata-biskupa. Kolektor nie wykorzystał okazji, jaką dawała mu służba dla Stolicy Apostolskiej, by jego kariera miała zasięg ogólnopolski, a nie tylko lokalny, mazowiecki. Z późniejszego czasu nie są znane żadne prowizje papieskie na kolejne beneficja dla Zygmunta.

W 1449 r. Mikołaj V mianował nowym kolektorem w Polsce Mikołaja Spicymira z Krakowa ${ }^{68}$, prawnika, pochodzącego z krakowskiej rodziny mieszczańskiej, który urząd papieskiego poborcy objął już po raz drugi. Jak wspomniałem, pierwszy raz był zwierzchnikiem polskiej kolektorii po śmierci Giacomina Rossiego. Subkolektorem generalnym w Polsce został 16 II 1437 r., a rok później (17 I 1438) kolektorem generalnym w Królestwach Polski i Czech ${ }^{69}$. W momencie nominacji w $1437 \mathrm{r}$. Mikołaj posiadał już liczne beneficja: prepozyturę kolegiaty Św. Idziego we Wrocławiu, kantorię i kanonię w katedrze wrocławskiej oraz altarię w krakowskim kościele Św. Anny ${ }^{70}$. Co ciekawe, z wyjątkiem altarii, beneficja te uzyskał dzięki prowizjom papieskim w ciągu trzech lat poprzedzających objęcie kolektorii polskiej ${ }^{71}$. Łatwość uzyskiwania papieskich nadań wynikała zapewne z kontaktów nawiązanych w Kurii

${ }^{66}$ BP V, nr 77, 1163; A. R a d z i m i ń s k i, Prałaci i kanonicy kapituły katedralnej płockiej w XIV i I poł. XV w., t. I, Toruń 1998, s. 155-156; zob. też RG V, nr 8299.

${ }^{67}$ MPV X, nr 507; zob. też BP V, nr 1298, VI, nr 923, 948.

${ }_{68}$ M. Z w i e r c a n, w: PSB XLI (2002), s. 85-87; karierę dokładnie przedstawia P. D e m b i ń s k i, Poznańska kapituła katedralna schyłku wieków średnich. Studium prozopograficzne 1428-1500, Poznań 2012, s. 592-596, ale z błędami wynikającymi z wykorzystania wadliwych regestów w BP.

${ }^{69}$ M. D. K o w a $1 \mathrm{~s}$ k i, Proventus, s. 194. Nie należy mylić subkolektora generalnego (succollector unicus), który pełnił funkcję analogiczną do kolektora, ze zwykłymi subkolektorami, czyli pomocnikami powoływanymi w poszczególnych diecezjach przez kolektora generalnego.

${ }^{70} \mathrm{RG} \mathrm{V}, \mathrm{nr} 7286$ (bulle z 31 X 1436 i 28 I 1437); regesty w BP V, nr 569, 612, są niepełne i błędne. W 1. 1434-1437 Mikołaj toczył też spór o kanonię kielecką, ale nie zdołał jej objąć, o czym wyraźnie informują supliki i bulle z tego czasu.

71 W 1433 r. Spicymir uzyskał (kolejne już) papieskie nadanie kanonii wrocławskiej, którą zdołał objąć w posiadanie (BP V, nr 263). Jesienią 1434 r., znów dzięki papieskiej prowizji, uzyskał prepozyturę Św. Idziego, podając przy tym w suplice, że dzierżył wtedy również kanonię wrocławską i altarię u Św. Anny oraz miał prowizje papieskie na kantorię wrocławską i archidiakonat opolski (ASV, Reg. Lat. 326, f. 16r-18r; regest w BP V, nr 333, jest niepełny). Ze względu na powód wakansu prepozytura Św. Idziego podlegała rezerwacji papieskiej. Mocą papieskiej ekspektatywy Mikołaj próbował zająć kanonię kielecką (BP V, nr 307, zob. też nr 333), ale nie zdołał się wejść w jej posiadanie - ASV, Reg. Lat. 337, f. 232r-234r; 347, f. 100r-100v (regesty w BP V, nr 569, 612, są niepełne i błędne); RG V, nr 7286. 
w czasie pobytu w Rzymie w latach 1432-1433, zwłaszcza że został wtedy notariuszem Roty Rzymskiej (causarum Palatii Apostolici notarius) ${ }^{72}$.

Niedługo przed nominacją na subkolektora generalnego Mikołaj Spiczmer otrzymał 31 X 1436 r. papieską prowizję na kantorię krakowską, wakującą po śmierci Giacomina Rossiego ${ }^{73}$. Warunkiem jej objęcia było zwolnienie prepozytury Św. Idziego. Mikołaj uzyskał przy tej okazji dyspensę na kumulowanie dwóch dowolnych beneficia incomapatibilia, ale tylko przez 2 lata. Wkrótce jednak (28 I 1437) papież zgodził się na wydłużenie tej dyspensy do końca życia ${ }^{74}$. Zgodę na dożywotnią kumulację inkompatibiliów można już wiązać z planem powierzenia Spicymirowi urzędu kolektora, co nastąpiło zaledwie pół miesiąca później. Warto zauważyć, że bulla prowizyjna została wyekspediowana dopiero w kwietniu 1437 r., a więc po otrzymaniu dożywotniej dyspensy i po nominacji na kolektora. Zanosiło się na to, że realizacja prowizji na kantorię krakowską będzie dużo trudniejsza niż w przypadku wcześniejszych nadań papieskich. Giacomino Rossi nigdy nie zdołał objąć owej prałatury, choć de iure był legalnym kantorem. W 1436 r. jej faktycznym posiadaczem był Wincenty Kot z Dębna. Wkrótce nastąpił jednak rzeczywisty wakans na kantorii, gdy Wincenty Kot postąpił na stolicę arcybiskupią w Gnieźnie. Elekcja kapituły dokonała się 29 października, a formalne potwierdzenie papieskie miało miejsce w marcu 1437 r. $^{75}$ Zwolniona w ten sposób (per promotionem) kantoria podlegała rezerwacji papieskiej, a prowizję od Eugeniusza IV uzyskał Tomasz Strzępiński ${ }^{76}$. Zanosiło się więc na kolejny długotrwały proces, ale ostatecznie obaj pretendenci doszli do porozumienia $^{77}$. W zamian za krakowską prałaturę Mikołaj Spicymir odstąpił Strzępińskiemu swoją kanonię we Wrocławiu ${ }^{78}$, a nowy nabytek dodatkowo potwierdziła kolektorowi w grudniu 1437 r. prowizja papieska (tzw. nova provisio) ${ }^{79}$. Zgodnie z wymogami prawa kanonicznego i z deklaracją złożoną w suplice, po objęciu prałatury w Krakowie Mikołaj zwolnił prepozyturę Św. Idziego we Wrocławiu ${ }^{80}$. Na przełomie 1437 i 1438 r. kolektor dzierżył więc następujące trzy beneficja: kantorię w kapitule katedralnej we Wrocławiu, kantorię w kapitule krakowskiej oraz altarię w kościele Św. Anny w Krakowie.

${ }^{72}$ Codex diplomaticus Poloniae, t. II, cz. 1, wyd. L. Rzyszczewski, A. Muczkowski, Warszawa 1848, nr 384, s. 471 (19 IX 1432); zob. też RG V, nr 306 (ASV, Reg. Suppl. 342, f. 3r: dictus Nicolaus Spiczmur fuerit alicuius ex sacri Palacii Apostolici causarum auditoribus notarius).

73 ASV, Reg. Lat. 337, f. 232r-234r (regest w BP V, nr 569, jest niepełny, z błędami i bez daty ekspedycji); BP V, nr 670; zob. RG V, nr 7286 (31 X 1436).

${ }^{74} \mathrm{RG} \mathrm{V}, \mathrm{nr} 7286$ (28 I 1437); regest w BP V, nr 612, jest błędny.

75 A. Ś wi e ż a w s ki, w: PSB XIV (1968-1969), s. 450-452. Informacja o zaistniałym faktycznym wakansie na krakowskiej kantorii nie mogła dotrzeć jeszcze do Kurii, gdy papież rozpatrywał suplikę 31 X $1436 \mathrm{r}$.

${ }^{76} \mathrm{BP}$ V, nr 637.

${ }_{77}$ Można przypuszczać, że zgoda Strzępińskiego na opisaną niżej transakcję wymiany mogła wynikać ze świadomości, że prawa Spicymira do kantorii były jednak mocniejsze. W świetle prawa kantoria zawakowała po śmierci Giacomina Rossiego, a nie po promocji Wincentego Kota, nieprawego posiadacza.

${ }^{78} \mathrm{BP} \mathrm{V}, \mathrm{nr} 751$ (i ponownie, błędnie pod nr 588); MPV X, nr 461.

${ }^{79} \mathrm{BP}$ V, nr 752 (18 XII 1437); M. D. K ow a ls k i, Rola prowizji, s. 185.

${ }^{80} \mathrm{RG} \mathrm{V}$, nr 306, 3784. 
Wkrótce, wraz z większością polskiego duchowieństwa, Mikołaj Spicymir opowiedział się za soborem, zrywając z papieżem Eugeniuszem IV. Stan taki trwał aż do końca schizmy bazylejskiej. W tym czasie nastąpiły pewne zmiany w stanie posiadanych przez Mikołaja beneficjów, ale zmiany te nie są dobrze uchwytne w źródłach. Około 1442 r. opuścił kantorię katedralną we Wrocławiu ${ }^{81}$. Dwa lata później poświadczony jest jako prebendarz kościoła Św. Wojciecha na Rynku krakowskim, którą to prebendę przed 23 VI $1444 \mathrm{r}$. zamienił z Michałem z Krosna na altarię w krakowskim kościele Św. Marii Magdaleny ${ }^{82}$. Nie wiadomo, kiedy i z czyjego nadania objął kościół Św. Wojciecha, ale być może uzyskał go w drodze zamiany za altarię w kościele Św. Anny, gdyż po 1437 r. nie pojawił się w źródłach jako jej posiadacz. Wreszcie wiosną 1449 r. uniwersytet prezentował go na uniwersytecką prebendę kościoła Św. Marii Magdaleny w Krakowie ${ }^{83}$.

Dnia 24 IV 1449 r. Mikołaj Spicymir został ponownie powołany na kolektora generalnego w Królestwie Polskim przez Mikołaja $\mathrm{V}^{84}$. Zatwierdzany przez kolejnych papieży sprawował ten urząd do swej śmierci 20 lat później ${ }^{85}$. W pierwszych latach urzędowania jego kariera beneficjalna doznała gwałtownego przyspieszenia. W 1450 r. ponownie wystąpił w źródłach jako kanonik wrocławski, choć nie można wykluczyć, że prebendę kanonicką przy katedrze wrocławskiej uzyskał wcześniej, przy okazji ustąpienia $z$ tamtejszej kantorii ${ }^{86}$. Następnie, 13 I 1451 r., pojawił się w źródłach jako jeden z dwóch plebanów (tzw. pleban domu murowanego) kościoła Wszystkich Świętych w Krakowie, uzyskując od papieża przywilej odpustowy dla wiernych odwiedzających tę świątynię ${ }^{87}$.

Prawdziwy przełom w karierze beneficjalnej Spicymira nastąpił jednak w latach 1453-1456. W połowie października $1453 \mathrm{r}$. kolektor otrzymał papieską prowizję motu proprio na dziekanię poznańską, mającą zawakować po objęciu arcybiskupstwa przez Jana ze Sprowy, a więc w sposób podlegający papieskiej rezerwacji. Papież polecił też unieważnić wszystkie inne supliki i bulle z prowizją na dziekanię, jeśli jakieś zostały wydane. Ponadto dokument papieski udzielał Mikołajowi dość rzadkiej dyspensy na dożywotnie kumulowanie aż trzech beneficjów niekompatybilnych ${ }^{88}$. W marcu następnego roku Mikołaj uzyskał papieską prowizję motu proprio na prepozyturę

${ }^{81}$ K. D o 1 a, Wrocławska kapituła, s. 32, 399-400.

82 Zbiór dokumentów katedry i diecezji krakowskiej, wyd. S. Kuraś, cz. 2, Lublin 1973, nr 467.

${ }^{83}$ Codex epistolaris saeculi decimi quinti, t. I, cz. 2, wyd. A. Lewicki, Kraków 1894 , nr 62; P. D e m b i ń s k i, Poznańska kapituła, s. 594.

${ }^{84}$ W 1448 r. kolektoria polska nie miała zwierzchnika. Mikołaj V wysłał wtedy do Królestwa swojego legata, Battistę Enrici z Rzymu, biskupa Camerino, wyposażając go w uprawnienia kolektorskie. Przejawiały się one m.in. w ustanawianiu przez legata subkolektorów, w celu przeprowadzenia zbiórki świętopietrza. W diecezji krakowskiej subkolektorem został Mikołaj Spicymir (ASV, Arm. XXXIII, vol. 24, f. 10v).

${ }^{85}$ M. D. K o w a ls ki, Proventus, s. 195.

${ }^{86}$ K. D o l a, Wrocławska kapituła, s. 399-400.

${ }^{87}$ BP VI, nr 509. Beneficjum plebana w kościele Wszystkich Świętych Mikołaj mógł otrzymać w drodze zamiany za prebendę u Św. Marii Magdaleny; zob. też Cracovia artificum. Supplementa 1462-1475, wyd. B. Przybyszewski, Kraków 2000, s. 44.

${ }^{88}$ ASV, Reg. Lat. 487, f. 197r-199r (15 X 1453), regest w BP VI, nr 727, jest bardzo niepełny; suplika reformacyjna: BP VI, nr 784; MPV X, nr 516. Obok kantorii krakowskiej 
poznańską, wakującą po śmierci Wyszoty z Górki, notariusza papieskiego, a więc znów w sposób podlegający papieskiej rezerwacji. Prowizji towarzyszył warunek rezygnacji z praw do niedawno nadanej dziekanii ${ }^{99}$. W obu przypadkach prowizji nie udało się Mikołajowi zrealizować, gdyż beneficja te przypadły konkurentom - dziekanię objął ostatecznie Adam z Dąbrowy ${ }^{90}$, a prepozyturę dostał dzięki poparciu królewskiemu Uriel z Górki ${ }^{91}$. W sprawie prepozytury Spicymir wszczął proces w Rocie przeciwko Urielowi i uzyskał nawet korzystny wyrok, ale ostatecznie obaj adwersarze zawarli ugodę ${ }^{92}$. Jej elementem musiało być zwolnienie kanonii poznańskiej przez Uriela, a zapewne i przesunięcia na kolejnych prebendach, które nastąpiły w $1455 \mathrm{r}$.

Dodatkową dogodną okolicznością, która pomogła w rozwiązaniu sporu o dziekanię i prepozyturę w Poznaniu, stała się elekcja Tomasza Strzępińskiego na biskupstwo krakowskie (25 V 1455), w wyniku czego miały zawakować wszystkie opuszczane przez niego prebendy. $Z$ racji wakansu per promotionem podlegały one rezerwacji papieskiej. Pozwoliło to na wyznaczenie Spicymirowi odpowiedniej rekompensaty, nie ograniczającej się do kanonii poznańskiej. Dnia 24 VII 1455 r. Mikołaj złożył w Stolicy Apostolskiej suplikę o kanonie w Gnieźnie, Poznaniu i Kruszwicy, wakujące po rezygnacji Jakuba Kota z Dębna ${ }^{93}$. Beneficja te Spicymir objął jednak w drodze prowizji biskupich, Jakub Kot bowiem rezygnował z nich na ręce właściwych ordynariuszy, a ci nadali prebendy kolektorowi. Nadanie jednej osobie jednorazowo aż trzech kanonii (w tym dwóch katedralnych), i to przez trzech różnych biskupów, nie było rzeczą zwyczajną i należy uznać, że była to uzgodniona rekompensata za rezygnację z praw do poznańskich prałatur. Bez wątpienia tak było w odniesieniu do kanonii poznańskiej, gdyż obejmując prepozyturę, Uriel z Górki zrezygnował z prebendy kanonickiej, na którą przeszedł Jakub Kot, zrzekając się z kolei dotychczasowej prebendy na rzecz Spicymira ${ }^{94}$. Prebenda gnieźnieńska zwolniła się z powodu promocji Tomasza Strzępińskiego na biskupstwo krakowskie i ostatecznie przeszła w ręce Mikołaja na identycznej zasadzie ${ }^{95}$. Nie wiadomo, dlaczego Jakub Kot zrzekł się także kanonii kruszwickiej, ale zapewne mechanizm był podobny. Bulle papieskie, finalizujące przesunięcia na prebendach pomiędzy owymi trzema duchownymi, zostały wydane w krótkim czasie między 25 IX a 16 X 1455 r., zaraz po papieskiej promocji Tomasza Strzępińskiego na biskupstwo (25 IX 1455) ${ }^{96}$. Ze względu na

i plebanii kościoła Wszystkich Świętych, dziekania poznańska byłaby trzecim beneficjum niekompatybilnym w posiadaniu Mikołaja.

${ }^{89}$ RG VI, nr 4591 (bulla z 2 III 1454); regest w BP VI, nr 778, jest niepełny; MPV X, nr 530.

${ }^{90}$ BP VI, nr 943 (2 X 1455); P. D e m b i ń s k i, Poznańska kapituła, s. 341-342, 592-596, 737.

${ }^{91}$ BP VI, nr 944 (2 X 1455); P. D e m b i ń s k i, Poznańska kapituła, s. 682-683, 735.

${ }^{92}$ BP VI, nr 944; P. D e m b i ń s k i, Poznańska kapituła, s. 593, 683. Wbrew twierdzeniu P. Dembińskiego, ugoda z Urielem nie przewidywała wypłacania Mikołajowi pensji, gdyż w suplice jest mowa jedynie o dochodach pobranych przez Uriela w czasie, gdy zajmował on sporną prałaturę nieprawnie, czyli w 1. 1454-1455. Tak więc elementem ugody musiało być zwolnienie przez Uriela kanonii poznańskiej.

${ }_{93}$ BP VI, nr 919; RG VII, nr 2289.

${ }^{94}$ P. D e m b iń s k i, Poznańska kapituła, s. 399, 682.

${ }_{95}$ BP VI, nr 939; P. D e m b iń s k i, Poznańska kapituła, s. 399.

${ }^{96}$ BP VI, nr 937, 939, 943, 944, 952; L. K o r c z a k, w: PSB XLV (2007-2008), s. 82. 
fakt, że Jakub był pokojowcem Mikołaja V (mogło zachodzić podejrzenie rezerwacji papieskiej), Spicymir postarał się o dodatkowe potwierdzenie papieskie i 16 października otrzymał stosowną prowizję (nova provisio) wydaną w trybie motu proprio ${ }^{97}$. W tym samym czasie (25 IX 1455) Spicymir otrzymał ponadto papieską prowizję motu proprio na kanonię krakowską po Strzępińskim ${ }^{98}$. W nadaniu zamieszczono klauzulę o anulowaniu innych, wystawionych dla kogokolwiek dokumentów prowizyjnych na to beneficjum ${ }^{99}$.

W ten sposób, uzyskawszy niemal równocześnie aż cztery prebendy kanonickie, polski kolektor stał się jesienią 1455 r. posiadaczem co najmniej siedmiu bogatych i prestiżowych beneficjów: kantorii krakowskiej, kanonii katedralnych w Krakowie, Gnieźnie, Poznaniu i Wrocławiu, kanonii w Kruszwicy i kościoła parafialnego Wszystkich Świętych w Krakowie. Cieszył się też dyspensą na kumulowanie trzech beneficjów niekompatybilnych. Aby mieć możliwość łatwiejszego dysponowania dochodami i kierowania swoją karierą, kolektor uzyskał jeszcze od papieża prawo do zamiany dzierżonych beneficjów (licentia permutandi), rezygnacji z nich na rzecz wskazanej osoby (licentia resignandi) lub do testamentowego rozporządzenia posiadanymi dobrami (licentia testandi), które bez takiego zezwolenia przeszłyby w razie śmierci na własność Kamery Apostolskiej ${ }^{100}$.

Nie dziwi fakt, że po 1455 r. nie zwiększyła się już liczba trzymanych przez Mikołaja Spicymira beneficjów, ale jego stan posiadania trochę się zmienił. W $1462 \mathrm{r}$. postanowił złożyć na ręce papieża rezygnację z kanonii kruszwickiej, a o mającą zawakować kanonię zabiegał w Stolicy Apostolskiej Walenty z Bochni, prawdopodobnie związany w jakiś sposób z kolektorem ${ }^{101}$. Trzy lata później Mikołaj zrezygnował $z$ altarii Św. Marty w katedrze krakowskiej na rzecz swojego krewniaka Jana Morsztyna $^{102}$. Altarię tę kolektor musiał uzyskać w wyniku zamiany za któreś z wcześniej posiadanych beneficjów. W 1466 zamienił kanonię poznańską z Wincentym Kiełbasą z Tymieńca na nieznaną prebendę ${ }^{103}$, a w 1467 r. ostatni raz wystąpił w źródłach z tytułem kanonika krakowskiego ${ }^{104}$, co może oznaczać, że i to beneficjum zamienił

97 ASV, Reg. Suppl. 485, f. 97r, oraz suplika reformacyjna: BP VI, nr 920; Reg. Lat. 505, f. 222r-223v (regest w BP VI, nr 952, jest niepełny, a ta sama bulla podana błędnie po raz drugi jako nr 967).

98 ASV, Reg. Suppl. 484, f. 291r; Reg. Vat. 438, f. 281r-282v (regest w BP VI, nr 938, jest niepełny).

${ }_{99}$ Również wystawiona tego samego dnia prowizja na kanonię gnieźnieńską po Strzępińskim, którą otrzymał Jakub z Dębna (BP VI, nr 939), zawierała podobną klauzulę. Na tej podstawie skasowana została prowizja dla Mikołaja z Sienna (tamże, nr 917, z błędną informacją, że chodzi o kanonię krakowską). Na marginesie księgi, obok skasowanej bulli (ASV, Reg. Vat. 438, f. 7r), wpisano mandat papieski z nakazem unieważnienia dokumentów konkurencyjnych względem bulli dla Mikołaja Spicymira i Jakuba Kota (w BP VI, nr 989, jako osobna pozycja).

${ }_{100}$ BP VI, nr 982 (w jednym regeście połączone dwie supliki), 1247, VII, nr 184; RG VII, nr 2289.

${ }^{101}$ BP VI, nr 1778 (ASV, Reg. Suppl. 553, f. 132v-133r); RG VIII, nr 1124 (19 VIII 1462). W 1453 r. Walenty syn Piotra Bochni składał w imieniu Mikołaja Spicymira obligację annatową (MPV X, nr 516).

102 BP VII, nr 206 (14 XI 1465).

103 P. D e m bi ń s k i, Poznańska kapituła, s. 593, 691.

104 RG IX, nr 2415 (regest w BP VII, nr 913, jest niepełny). 
na inne przed swoją śmiercią, która nastąpiła ok. 23 VI 1469 r. Aż do końca życia posiadał co najmniej sześć beneficjów: kantorię krakowską ${ }^{105}$, kanonie katedralne w Gnieźnie ${ }^{106}$ i Wrocławiu ${ }^{107}$, plebanię kościoła Wszystkich Świętych w Krakowie ${ }^{108}$, kanonię w Kurzelowie ${ }^{109} \mathrm{i}$ altarię w katedrze krakowskiej ${ }^{110}$. Dwa ostatnie beneficja uzyskał zapewne poprzez zamiany, dokonane w ostatnich latach życia ${ }^{111}$.

Zdobycie tak pokaźnej liczby beneficjów, zwłaszcza aż czterech prebend w $1455 \mathrm{r}$., byłoby niemożliwe bez szczególnej przychylności papieskiej, związanej z funkcją kolektora. Mikołaj Spicymir na pewno należał dzięki temu do grupy najbogatszych polskich duchownych, zwłaszcza jeśli dodać jego wynagrodzenie kolektorskie.

Po śmierci Mikołaja Spicymira papież Paweł II bullą z 18 V 1470 r. mianował kolektorem generalnym w Polsce Dziersława syna Michała z Karnic ${ }^{112}$. Nowy kolektor był prawnikiem po studiach w Krakowie, gdzie w 1453 r. uzyskał stopień bakałarza ${ }^{113}$, po czym przez wiele lat kontynuował naukę prawa kanonicznego na uniwersytecie w Rzymie ${ }^{114}$. Ostatecznie 5 II 1471 r. otrzymał tytuł doktora dekretów w Bolonii ${ }^{115}$, a w późniejszym czasie został doktorem obojga praw (1481) Podczas długiego pobytu w Rzymie (1455-1471) był zapewne związany z Rotą Rzymską, gdyż kilka razy występuje w źródłach jako sędzia papieski (1467-1469) ${ }^{117}$. $\mathrm{W}$ jednej z suplik z $1470 \mathrm{r}$. został określony mianem antiquus curialis ${ }^{118}$. Niewątpliwie to właśnie dzięki nawiązanym wtedy kontaktom uzyskał od papieża urząd kolektora. W chwili nominacji Dziersław posiadał już kilka ważnych beneficjów, które uzyskał dzięki papieskim ekspektatywom i prowizjom: scholasterię płocką (1456$1494)^{119}$, kanonię krakowską $(1466-1494)^{120} \mathrm{i}$ archidiakonat kurzelowski $(1467-1488)^{121}$,

\footnotetext{
105 BP VII, nr 719.

106 Tamże, nr 718.

107 Tamże, nr 720.

108 Tamże, nr 763.

109 Tamże, nr 721.

110 Tamże, nr 722.
}

111 Przypisywanie Mikołajowi Spicymirowi jeszcze innych beneficjów (kanonii włocławskiej i tarnowskiej) opiera się na ewidentnych pomyłkach, por. P. D e m b i ń s k i, Poznańska kapituła, s. 595.

${ }_{112}$ M. D. K o w a $1 \mathrm{~s} \mathrm{k}$ i, Proventus, s. 195.

113 Metryka Uniwersytetu Krakowskiego z lat 1400-1508, wyd. A Gąsiorowski, T. Jurek, I. Skierska, przy współpracy R. Grzesika, Kraków 2004, t. I, s. 222 (nr 48h/150); Najstarsza księga promocji Wydziału Sztuk Uniwersytetu Krakowskiego z lat 1402-1541, wyd. A Gąsiorowski, T. Jurek, I. Skierska, Warszawa 2011, s. 219 (nr 53/3).

114 BP VI, nr 1020, 1122, VII, nr 105, 535, 536; RG IX, nr 1009.

115 S. A. S r o k a, Wykaz Polaków wypromowanych na uniwersytecie w Bolonii w drugiej połowie XV wieku, Kwartalnik Historyczny 121, 2014, nr 1, s. 146.

116 MPV X, nr 809.

117 RG IX, nr 5907 (7 II 1469), 5312 (31 V 1467); BP VII, nr 383, 428, 666.

118 Tamże, nr 833.

119 Tamże VI, nr 1047, VII, nr 536; MPV X, nr 1000, 1004. Choć przez kilka lat po otrzymaniu prowizji spierał się w Rocie Rzymskiej o scholasterię, to cały czas pozostawał w jej posiadaniu.

${ }_{120}$ BP VII, nr 322; MPV X, nr 1001; Cracovia artificum. Supplementa 1451-1460, wyd. B. Przybyszewski, Kraków 2001, nr 132, s. 96.

121 BP VII, nr 497; RG IX, nr 1009 (24 XI 1467); MPV X, nr 909 (26 II 1488). 
a może też inne ${ }^{122}$. Po zaledwie dwóch latach Dziersław złożył urząd kolektora i rozliczył się z Kamerą Apostolską ze swej działalności ${ }^{123}$.

O ile podczas pobytu w Rzymie Dziersław otrzymał wiele ekspektatyw i prowizji papieskich, to z okresu działalności kolektorskiej nie ma ich prawie wcale. Jeszcze przed wyjazdem z Wiecznego Miasta do kraju postarał się tylko o dyspensę na kumulowanie dwóch beneficjów niekompatybilnych ${ }^{124}$. Jednym z powodów braku papieskich nadań mógł być fakt, że przebywając w Polsce, nie mógł na bieżąco reagować na informacje o wakansach, jak działo się to podczas pobytu w Rzymie, a nie planując dłuższego sprawowania funkcji kolektora, nie starał się zabiegać o nie przez wysłanników. Poza tym trzeba pamiętać, że posiadał już i tak bardzo pokaźne uposażenie.

Wiadomo, że w latach 1480-1481 (a także później) Dziersław podróżował jeszcze do Rzymu i pozyskiwał kolejne łaski od papieża. Dzięki prowizji z grudnia $1480 \mathrm{r}$. został prepozytem kolegiaty Św. Michała w Płocku (1480-1490) ${ }^{125}$. Na początku 1488 r. Innocenty VIII przyznał mu facultatem resignandi et permutandi wszystkich posiadanych beneficjów ${ }^{126}$. Ponadto w 1490 r. Dziersław poświadczony jest jako oficjał i wikariusz generalny płocki ${ }^{127}$. Dokładne odtworzenie kariery Dziersława z Karnic jest bardzo trudne, ze względu na niewielką liczbę wydanych źródeł z drugiej połowy XV w., w tym zwłaszcza źródeł papieskich z okresu po $1471 \mathrm{r}$. Dostępne przekazy pozwalają jednak sądzić, że Karnicki zawdzięczał swą karierę przede wszystkim nadaniom papieskim. Jako zaufanemu kurialiście powierzono mu kolektorię w Królestwie Polskim, ale sprawował ją krótko i nie wpłynęło to znacząco na dalszy rozwój jego kariery kościelnej. Nie bez znaczenia było z pewnością także posiadane wykształcenie prawnicze, które predestynowało go do wysokich stanowisk. Dziersław zmarł przed 30 I 1494 r. ${ }^{128}$

Kolejnym kolektorem w Królestwie Polskim został Andrzej Róża Boryszewski, pełniący tę funkcję w latach 1472-1475. Przez kilka lat (1463-1468) przebywał on w Rzymie i dzięki nawiązanym tam kontaktom uzyskał później nominację na papieskiego poborcę. Nie wywiązywał się należycie ze swoich obowiązków, przez 3 lata w aktach Kamery nie odnotowano żadnej dokonanej przez niego wpłaty, a na koniec urzędowania nie rozliczył się ze swej działalności, skutkiem czego podpadł pod ekskomunikę ${ }^{129}$.

${ }^{122}$ W 1. 1455-1469 Dziersław otrzymał wiele prowizji papieskich, w dużej części z pewnością niezrealizowanych, por. BP VI, s. 428, VII, s. 299 (indeksy); RG VII, nr 471, IX, nr 1009. O karierze Dziersława zob. też Cracovia artificum [1451-1460], nr 132, s. 96-97; Cracovia artificum. Supplementa 1462-1475, wyd. B. Przybyszewski, Kraków 2000, nr 180, s. 122 (w obu miejscach wiele informacji błędnych).

123 M. D. K ow a $1 \mathrm{~s} \mathrm{k} \mathrm{i,} \mathrm{Proventus,} \mathrm{s.} 195$.

124 BP VII, nr 891 (9 II 1471). Nie wiadomo, na jakiej podstawie Dziersław kumulował przez ostatnie kilka lat scholasterię płocką i archidiakonat kurzelowski. Albo miał tylko typową dyspensę czasową, albo przez dłuższy czas nie wszedł w rzeczywiste posiadanie archidiakonatu.

${ }^{125}$ MPV X, nr 809; Zbiór dokumentów i listów miasta Płocka, wyd. S. M. Szacherska, t. I, Warszawa 1975, nr 252.

126 MPV X, nr 909.

127 Zbiór dokumentów i listów miasta Płocka, t. I, nr 252.

${ }_{128}$ MPV X, nr 1000, 1001.

129 M. D. K ow a 1 s k i, Proventus, s. 196. 
Być może powodem było zaangażowanie $\mathrm{w}$ inne obowiązki, zwłaszcza dyplomatyczne. Jak wiadomo, Boryszewski zrobił świetną karierę kościelną i osiągnął godność prymasa. Oczywiście na karierę tę nie miała żadnego wpływu działalność w charakterze kolektora, choć raczej należałoby stwierdzić, że kolektorstwo nie zaszkodziło $\mathrm{mu} \mathrm{w}$ dalszej karierze ${ }^{130}$. Co ciekawe, w czasie pełnienia funkcji papieskiego poborcy nie starał się chyba w Rzymie o żadne prowizje, a po 1475 r. objął tylko dwa nowe beneficja niższe, z czego tylko jedno (prepozytura kruszwicka w 1492 r.) w drodze nadania papieskiego ${ }^{131}$.

Ostatnim średniowiecznym kolektorem w Polsce został Uriel syn Łukasza z Górki, piastujący ten urząd przez ponad 20 lat (1475-1496) ${ }^{132}$. W ciągu ćwierćwiecza poprzedzającego objęcie urzędu papieskiego poborcy Uriel zgromadził niezwykle pokaźną liczbę beneficjów. Dzięki poparciu wpływowego ojca, wojewody poznańskiego, został ponadto kanclerzem koronnym (1473-1479) ${ }^{133}$. Dochody beneficjalne wraz z wielkim majątkiem rodowym czyniły go zapewne jednym z najbogatszych duchownych w kraju. W 1479 r. Uriel z Górki został biskupem poznańskim (1479-1498), o czym zdecydowała wola królewska. Nominacja kolektorska nie miała więc żadnego wpływu na karierę Uriela, rozumianą jako awans w strukturach kościelnych. W latach 14751479 nie objął już żadnego nowego beneficjum. Zaskakujący jest zarówno fakt, że papież zgodził się, by kolektorem został urzędujący kanclerz królewski, jak i to, że urzędujący kanclerz zdecydował się na objęcie kolektorii, a także fakt, że z chwilą powołania na poznańską katedrę Uriel nie złożył papieskiego urzędu i stał się w ten sposób pierwszym od 80 lat biskupem pełniącym tę funkcję ${ }^{134}$. Wskazuje to na inne motywy niż te, którymi zwykle kierowali się duchowni zabiegający o objęcie kolektorii. Jeżeli weźmiemy pod uwagę zamożność biskupa, to i pensja papieskiego poborcy nie mogła mieć dla niego istotnego znaczenia ${ }^{135}$.

Zaprezentowany wyżej przegląd karier polskich kolektorów pozwala dostrzec pewne zjawiska i przybliżyć się do odpowiedzi na postawione we wstępie pytania. Wydaje się, że urząd kolektora papieskiego w Polsce w XV w. był już zbyt mało atrakcyjny, by przyciągnąć ważniejszych duchownych z zagranicy, dlatego obejmowali go

130 J. W i e s i o ł o w s k i, w: Wielkopolski słownik biograficzny, Warszawa-Poznań 1981, s. 75-76; P. D e m b iń s k i, Poznańska kapituła, s. 361-365.

${ }^{131}$ MPV X, nr 976; P. D e m b iń s k i, Poznańska kapituła, s. 363.

${ }_{132}$ M. D. K ow a ls ki, Proventus, s. 196.

133 J. G a r b a c i k, w: PSB VIII (1959-1960), s. 421-423 (gdzie jednak całkiem niewłaściwie ukazana została funkcja kolektora, traktowanego w kategoriach dyplomaty, jak i nierealistycznie ocenione zostało znaczenie sum zbieranych z tytułu świętopietrza); A. G ą s i o r o w s k i, w: Wielkopolski słownik biograficzny, s. 222; P. D e m b iń s k i, Poznańska kapituła, s. 682-685. Z biogramów tych czerpię wszystkie podane dalej informacje na temat kariery Uriela.

${ }^{134}$ Poprzednim był biskup poznański Dobrogost z Nowego Dworu (S. S z c z u r, Skarbowość papieska, s. 153).

${ }^{135}$ Ze swojego wynagrodzenia w wysokości 365 florenów rocznie (1 floren dziennie) kolektor musiał pokryć koszty swej działalności, w tym wynagrodzenie subkolektorów, które rocznie wynosiło ok. 110-120 florenów (na podstawie rachunków Uriela: Vetera monumenta Poloniae et Lithuaniae gentiumque finitimarum historiam illustrantia, wyd. A. Theiner, t. II, Romae 1861, nr 224). Uriel pisze nawet o poniesionej stracie ok. 1000 flor., którą to stratę wyrównał częściowo z własnych środków (tamże, s. 195). 
głównie Polacy. Każdy z papieskich poborców miał przed swoją nominacją jakiś związek z Kurią Rzymską. Niektórzy, jak Mikołaj Spicymir i Dziersław z Karnic, już od dłuższego czasu musieli cieszyć się zaufaniem papieża i dzięki papieskim prowizjom zdobyli pokaźną liczbę prebend. Chętnie widziano osoby posiadające wykształcenie prawnicze i większość kolektorów mogła się wykazać stopniem licencjata lub doktora dekretów. Tytułu nie miał Uriel z Górki, ale studiował prawo w Bolonii, Andrzej Boryszewski zaś był tylko mistrzem sztuk. Jedynymi osobami, o których wykształceniu uniwersyteckim niczego nie wiadomo, byli Giacomino Rossi i pokojowiec papieski Andrea de Palatio.

Nie jest zaskoczeniem, że najczęstszym powodem objęcia urzędu kolektorskiego była chęć zrobienia kariery kościelnej i podniesienia swego statusu materialnego. Niektórzy z papieskich poborców wyraźnie koncentrowali się na postępach swej kariery beneficjalnej, ale można dostrzec przy tym różne sposoby działania, nie ma jednego modelu kariery kolektorskiej. Mikołaj Spicymir był łowcą beneficjów, których zgromadził bardzo pokaźną liczbę - kumulował co najmniej siedem prebend. Inaczej postępował Piotr Wolfram. Zwykle posiadał tylko trzy beneficja, ale nieustannie je zamieniał i to tak umiejętnie, że skończył jako stołeczny prałat i kanonik w dwóch innych katedrach. Być może na chęć kumulowania przez niego kolejnych godności moderująco działał jeszcze reformatorski duch Konstancji. Warto przypomnieć, że Marcin V nie zgodził się przyznać Wolframowi dożywotniej dyspensy na dzierżenie dwóch inkompatybiliów. Przykładem kolektora pochłoniętego staraniami o beneficja jest też Giacomino Rossi, ale mimo licznych prowizji i wygranych procesów, osiągnął on relatywnie niewiele. Wyraźnie nie był w stanie przełamać oporu lokalnych środowisk. Można przypuszczać, że sprzeciw budziła sama osoba kolektora, prawdopodobnie niższego stanu niż polscy konkurenci (choć był szlachetnie urodzony) i zapewne o niższych walorach intelektualnych (nie miał wykształcenia uniwersyteckiego). W nieco podobnej sytuacji znalazł się Mikołaj Spicymir, gdy bezskutecznie usiłował zrealizować prowizje na dziekanię i prepozyturę w Poznaniu. Nie zdecydował się on wtedy na walkę sądową z miejscową elitą, tym bardziej że miał już prałaturę w Krakowie, ale szybko zawarł ugodę w zamian za rekompensatę $\mathrm{w}$ formie trzech prebend kanonickich. Pokazuje to wyraźnie, że chodziło mu przede wszystkim o kolejne źródła dochodów.

Charakterystyczne jest, że w przypadku trzech Polaków, którzy pełnili funkcje kolektorów przez krótki czas (Zygmunt z Giżyc, Dziersław z Karnic, Andrzej Boryszewski), nie widać niemal żadnej aktywności w pozyskiwaniu łask papieskich w czasie pełnienia urzędu, a sytuacja również niewiele się zmieniła po ich odejściu z kolektorstwa. A przecież Dziersław i Andrzej otrzymali przed nominacją kolektorską sporo papieskich prowizji, co zawdzięczali nawiązanym wcześniej w Kurii kontaktom. Oczywiście należy jeszcze uwzględnić czynnik przypadku, otrzymanie prowizji podczas dość krótkiego okresu urzędowania zależało bowiem od zaistnienia w tym czasie wakatu - w sposób podlegający rezerwacji papieskiej - na takim beneficjum, które mogło zainteresować kolektora, a więc np. dawało dużą szansę na zrealizowanie nadania, bez narażenia się na ciężki konflikt z lokalnym środowiskiem. Najwyraźniej zadowalające było samo wynagrodzenie kolektora, które stanowiło ekwiwalent bardzo dobrego beneficjum. Atrakcyjna 
mogła być też możliwość czasowego dysponowania sporą gotówką, zebraną $\mathrm{z}$ tytułu świętopietrza.

Kariery dłużej działających kolektorów (Wolfram, Rossi, Spicymir) wyraźnie pokazują, że motorem ich karier były papieskie prowizje na beneficja zarezerwowane Stolicy Apostolskiej. Nie chodzi przy tym tylko o łatwość ich uzyskiwania, ale także o ich rodzaj. Giacomino Rossi i Mikołaj Spicymir otrzymali wiele prowizji typu motu proprio, a więc lepszych niż zwykłe nadania, gdyż motu proprio dawało pierwszeństwo przed ewentualnymi innymi posiadaczami papieskich dokumentów ${ }^{136}$. Widać, że obeznani z rzeczywistością kurialną kolektorzy zabiegali o ten właśnie typ prowizji, licząc się z możliwymi rywalami. W swoich listach do przyjaciela-kurialisty Rossi pisał wprost, o jaki dokument należy się starać137. Giacomino nie wahał się też posłać papieżowi dwóch cennych futer, by pozyskać sobie jego przychylność138. Kolektorzy składali głównie supliki o wakujące beneficja podlegające rezerwacji papieskiej, czyli takie, którymi dysponować mógł jedynie papież. Oprócz tego otrzymywali także ekspektatywy, ale w razie objęcia na ich podstawie beneficjum i tak starali się potwierdzić ten fakt przez papieską prowizję (tzw. nova provisio). Funkcja papieskiego poborcy pozwalała na szybkie zdobycie informacji o pojawiających się wakansach na obszarze całego kraju i szybkie składanie suplik w Stolicy Apostolskiej. Można się było tego domyślać, ale listy Rossiego pokazują dokładnie, jak funkcjonował ten mechanizm w praktyce. W 1429 r. rezydujący w Krakowie Giacomino Rossi dowiedział się o mającym rychło nastąpić wakacie we Wrocławiu (posiadacz beneficjum był śmiertelnie chory) od działającego tam subkolektora i bezzwłocznie wysłał list do Kurii z prośbą o złożenie stosownej supliki. Gdy zaś w 1434 r. ten sam kolektor przebywał w Italii, wiadomość o wakacie na prepozyturze wrocławskiej przesłał mu natychmiast tamtejszy bankier i współpracownik. Pozwoliło to Rossiemu wyprzedzić konkurentów przy składaniu supliki. Licznym prowizjom papieskim towarzyszyły łaski dodatkowe. Do najważniejszych należały dyspensy - i to dożywotnie - na kumulację beneficjów niekompatybilnych, niekiedy nawet aż trzech ${ }^{139}$. Facultas permutandi pozwalała swobodnie zamieniać beneficja, czego najlepszym przykładem jest kariera Piotra Wolframa, facultas resignandi zaś pozwalała u schyłku życia przekazywać prebendy w ręce krewniaków czy współpracowników.

Poza względami czysto materialnymi nie można też zapominać o prestiżu, jaki wiązał się z pełnieniem urzędu kolektora. Papieski poborca był jedynym stałym przedstawicielem Stolicy Apostolskiej w Królestwie i pozostawał w stałym kontakcie z Kamerą Apostolską. Na początku urzędowania wyposażany był w specjalne facultates, które dawały mu uprawnienia, jakich nie posiadał żaden inny przedstawiciel miejscowego kleru. Była to m.in. możliwość udzielania określonej liczbie osób dyspens (małżonkom od przeszkody pokrewieństwa, kandydatom do stanu duchownego od defektu urodzenia itd.), zezwoleń na używanie ołtarzy przenośnych, a także prawo zdejmowania cenzur kościelnych, prawo mianowania notariuszy

136 P. R a bik a u s k a s, Diplomatica pontificia, wyd. 6, Roma 1998, s. 127.

137 Una corrispondenza, $\mathrm{nr}$ 30, 31, 33-35.

138 Tamże, nr 30.

139 Mikołaj Spicymir dostał taką dyspensę dożywotnio, a Giacomino Rossi - czasowo, zob. wyżej. 
publicznych itp. ${ }^{140}$ Łaski duchowe, którymi mógł dysponować papieski poborca, były pożądane przez wielu duchownych i świeckich. Oczywiście, oprócz prestiżu kolektor niejednokrotnie ściągał na siebie zapewne również niechęć płatników.

Jak już wcześniej zaznaczyłem, chęć wzbogacenia się i zrobienia kariery w strukturach kościelnych nie mogły być powodami, dla których urząd papieskiego kolektora w Królestwie Polskim zdecydował się objąć Uriel z Górki. Gdy w 1479 r. został biskupem poznańskim, nie rezygnując z kolektorii, jedynym możliwym awansem ordynariusza poznańskiego mogło być już tylko przejście na inną katedrę, ale to zależało od króla, a nie od papieża. Jedynym wyjaśnieniem wydaje się w tej sytuacji możliwość korzystania przez Uriela z uprawnień, jakimi dysponował papieski poborca. Z racji normalnych obowiązków jurysdykcja kolektora generalnego rozciągała się na całą prowincję gnieźnieńską, w zakresie spraw dotyczących Kamery Apostolskiej. Między innymi mógł on nakładać cenzury kościelne i udzielać absolucji płatnikom. W ten sposób władza poznańskiego biskupa wykraczała poza granice jego własnej diecezji, obejmując obszary podlegające innym hierarchom. Ustanawiani przez kolektora generalnego subkolektorzy, rekrutujący się z miejscowego kleru, działali w każdej diecezji i mogli dostarczać cennych informacji swojemu przełożonemu. Ponadto Uriel mógł korzystać z opisanych wyżej facultates. Obowiązki, które polegały prawie wyłącznie na zbieraniu świętopietrza, wykonywali niemal w całości subkolektorzy.

Jak pokazuje przykład papieskich kolektorów w piętnastowiecznej Polsce, choć podstawowym powodem starania się o ten urząd była chęć zdobycia nowych beneficjów i przyspieszenia kariery kościelnej oraz atrakcyjność wynagrodzenia kolektorskiego, to istotne były także inne aspekty, wiążące się z zakresem władzy funkcjonariuszy Kamery Apostolskiej. Biorąc pod uwagę wszystkie czynniki, kolektorów generalnych zaliczyć należy z pewnością do elity polskiego duchowieństwa swego czasu.

\section{Warum lohnte es sich, Kollektor zu werden? Karrieren päpstlicher Generalkollektoren im Polen des 15. Jahrhunderts}

\section{Zusammenfassung}

In den Jahren 1418-1496 waren nacheinander neun päpstliche Generalkollektoren im Königreich Polen tätig. Die Päpste übertrugen dieses Amt meist solchen Klerikern, die bereits früher mit der römischen Kurie verbunden waren. Beinahe alle von ihnen verfügten über eine kanonistische Universitätsbildung. Der Blick auf die Karrieren der päpstlichen Kollektoren in Polen zeigt, daß der eigene Aufstieg innerhalb der Kirchenstrukturen und die finanzielle Attraktivität des Kollektorenamtes zu den Hauptmotiven für den Eintritt in den Dienst der Apostolischen Kammer zählten. Die besonderen Rechte, die den Kollektoren von den Päpsten zugestanden wurden, garantierten ihnen eine Sonderstellung innerhalb der Ortsgeistlichkeit. Vier Kollektoren verwalteten ihr Amt sehr lange (8-23 Jahre). Zum Motor für ihre Karrieren wurden zahlreiche Provisionen für die dem Apostolischen Stuhl reservierten Benefizien, dank derer sie zahlreiche prestigeträchtige Pfründen erlangen konnten. Die Kollektoren bemühten sich häufig um Verleihungen Motu Proprio, da diese Form für den Providierten die günstigste

${ }^{140}$ Zob. BP IV, nr 1659-1669, V, nr 772-778, 920-928, VI, nr 494-502. 
war. Sie bekamen auch andere Gnadenerweise, so z. B. Dispense von der Kumulation inkompatibler Benefizien. Informationen über Vakanzen auf wertvollen Präbenden erhielten sie von ihren Subkollektoren und anderen Mitarbeitern zeitnahe aus der gesamten Kirchenprovinz, was ihre Chancen auf schnelle Einreichung entsprechender Suppliken bedeutend erhöhte. Als Ausnahmekollektor ist Uriel von Górka (1475-1496) anzusehen, der diese Aufgaben als königlicher Kanzler und ab 1479 auch noch als Bischof von Posen erfüllte.

Übersetzt von Waldemar Könighaus

\section{Why was it worthwhile to become a collector? Careers of papal collectors general in Poland in the $15^{\text {th }}$ century}

Abstract

Papal collectors were responsible for collecting all taxes for the Holy See from the clergy on the territory (church province) entrusted to them. The paper presents the careers of nine collectors active in Poland in the fifteenth century, in order to discover the motifs which made them undertake the duties of a collector, as well as how the service to the Apostolic Camera influenced their careers. Analysis of individual careers shows how they utilised papal provisions and other favours in practice to obtain further benefices. Discussed are also additional benefits - other than the financial ones - which resulted from fulfilling the office of the head of the papal collectorate. 